Social Death and the Moral Identity of the Fourth Age

Chris Gilleard Ph.D. and Paul Higgs Ph.D.

UCL Division of Psychiatry

Faculty of Brain Sciences

6th Floor, Maple House,

149 Tottenham Court Road,

London W1T 7NF

E-mail: C.Gilleard@ucl.ac.uk 


\title{
Social Death and the Moral Identity of the Fourth Age
}

\begin{abstract}
The bleaker aspects of old age have been encapsulated in the concept of a fourth age which has been likened to a metaphorical 'black hole' where human agency is no longer visible. This paper explores what such a formulation might mean for the moral standing of mentally and physically infirm persons. Does the idea of a fourth age reinforce representations of dementia as a form of social death or does the status of those defined by the moral imperative of care benefit from the narratives and practices of their carers who keep socially alive such persons whatever their degree of dementia? This paper argues that those persons at risk of being enveloped by the fourth age are not inherently deprived of a social life even if it is a social life that their previous self would not have chosen. The moral imperative of care forms a key part element of the fourth age - for both good and ill. Recognising the role of carers in realising or rejecting the fourth age imaginary means also valuing their agency.
\end{abstract}

Key words: Fourth age, moral identity, dementia, social death

Words: 176

Total word count: 6070 


\section{Social Death and the Moral Identity of the Fourth Age}

\section{Introduction}

In a paper published in the Lancet in 2010 Daniel George wrote: "The everyday language we use to describe dementia shapes our perceptions of brain ageing and even contributes to what has been called the "social death" of those most severely affected" (George, 2010: 586). He goes on to argue that not only does the language used about dementia "guide feelings of enmity and fear" but it also leads to dementia being seen "as something external of us". In identifying the contribution of language to the construction of the social death of people with dementia, George helps situate the concerns of this paper which are to consider the nature of the social identity attributed to mentally frail old people what we have termed the 'social imaginary' of the fourth age. In particular we are interested in examining whether the fourth age, conceived in this way, necessarily condemns people to 'social death' and therefore places them outside of social relations (Higgs and Gilleard, 2015). This question is important because the idea of the social death of the person with dementia is one which is increasingly rejected in most contemporary accounts of the social relations surrounding dementia in favour of positions supporting the continuing role of 'personhood' (Dewing, 2008; Kitwood, 1997). For those advocating a personhood approach the difficulty with the concept of social death is that it implies the loss of personhood while the individual with dementia is alive and therefore deprives him or her of their 'human rights'.

However, if the fourth age is thought of as 'ageing without agency' (Gilleard and Higgs, 2010) the challenge for people with dementia is less about their personhood going unrecognised as their various dependencies that position them under the agency of others through the 'imperative of care'. Once activated this imperative of care provides (for good or for ill) a necessary scaffolding potentially preventing the social death of the person with 
dementia while potentially foreclosing other aspects of personhood. The social imaginary of the fourth age may keep alive the identity of the person with dementia but it also serves to frame the individual as a non-agentic object of concern even while maintaining the individual in the complex pattern of social and cultural relations that constitutes caring.

These arguments might seem to run contrary to much discussion about dementia and personhood. To expound our argument we need to start by defining our terms. This we do in the first part of this paper, by explicating the concepts of 'the fourth age', 'moral identity' and 'social death'. In the second half of the paper, we address the various possible relationships between these terms. We conclude by arguing that mentally frail old people can be maintained as socially alive persons, even as their care is carried out under the aegis of the fourth age, and despite being considered as having a limited or even lost agency.

\section{The fourth age}

The concept of 'the fourth age' was introduced into modern gerontology by Peter Laslett, in his book A Fresh Map of Life (Laslett, 1989; 1996). Laslett described the fourth age as a period of dependency and decrepitude, which he contrasted with the autonomy and achievement in later life that he attributed to the third age when the responsibilities of work and family were shed and opportunities for self-fulfilment beckoned (Laslett, 1996: 192). While Laslett saw the fourth age as a final stage of life normally occurring after the third age had been attained, he acknowledged that for some illness may cause a rapid fall into the fourth age, with no opportunity for any third age, while for others death may come so swiftly it pre-empts the possibility of a fourth age. 
Paul Baltes took up the theme of the fourth age which he located as a distinct chronological period associated with the age of the oldest old, typically after the age of 80 (Baltes and Smith, 2003). He likened the division between the third and fourth age to the American psychologist Bernice Neugarten's earlier distinction between the 'young' old (60-74) and the 'old' old (75+) (Neugarten, 1974). But for Baltes, this divide represented more than a matter of mere chronology. For him, there was a significant qualitative distinction between the empirically realisable possibilities of the third age and the intractability of loss that characterised the fourth (Baltes, 2006). Baltes' conceptualisation of the fourth age resonated with the earlier idea of 'terminal decline' which argued for a distinction between the positive growth of years lived since birth and the deterioration taking place in the years leading up to death (Palmore \& Cleveland, 1976).

In our own work we have provided an alternative approach to the fourth age which differs markedly in its point of reference. Based neither on any fixed bio-chronology nor on individual stages of life, we proposed that the fourth age is a social imaginary (Gilleard and Higgs, 2010; Higgs and Gilleard, 2015). We draw the1 term 'social imaginary' from the work of the French theorist, Cornelius Castoriadis in his The Imaginary Institution of Society to refer to the way that society and its institutions are given meaning by its members (Castoriadis, 1987). For Castoriadis, the function of 'social imaginaries' is to give meaning to modern society's unstructured and inarticulate sense of the world (Castoriadis, 1987: 39). Social imaginaries have both a creative function - ascribing changing or inventing meanings for social institutions and practices - and an alienating aspect, when these meanings take on a life of their own, excluding or proscribing alternative meanings and interpretations (Castoriadis, 1987). For the Canadian philosopher Charles Taylor, social imaginaries provide the social cognitions supporting mutual expectancies and social trust - the sense of 
togetherness (Taylor, 2002). The role of 'public opinion' and the 'mass media' serve as important vehicles in conveying the outlines of modern social imaginaries - whether positively as in 'our team', 'our government' or 'our boys' - or negatively as in 'those gypsies', 'those immigrants' or simply 'those people'.

Old age, we have suggested, has long functioned as such a social imaginary, a social position that is either loved, respected or feared, sought after or shunned, attributed power or denied it; in short a term whose cultural meaning is open to interpretation of what it means to be 'old'. The fourth age is the dark side of this imagined old age, the repository of all the feared and disdained aspects of age and agedness. In contrast to the authority of age with its notions of maturity and/or seniority, the fourth age is associated with senility and senescence. It is not our intention here to explore all the various influences shaping its imaginary (see Higgs and Gilleard 2015 for a fuller treatment); here we can only briefly outline what we consider to be the four key vectors making up its contemporary form before exploring in more detail one particular vector, the imperative of care and its role in defining what can be thought of as the moral identity of the fourth age.

\section{Vectors of the fourth age}

At the heart of the fourth age imaginary is the social construction of frailty (Higgs and Gilleard 2014), with its various relationships to bio-medicine, society and the moral universe. For some time bio-medical scientists have been preoccupied with identifying a syndrome of 'frailty' distinct from both age and disease, one that serves as a bio-marker of biological vulnerability. Associated with this 'laboratory science' have been those practicing clinicians who have sought to incorporate failures or dysfunctions in most organ systems, and in mental health and social resources, creating a bio-psycho-social omnivore that sucks up every late 
life falling into its maws The objectification of frailty represented by such biomedical endeavours is one important aspect of the fourth age. Another, equally important if rather different vector is that of abjection.

Abjection, as used by Georges Bataille in his essay 'Abjection and miserable forms', links certain social positions with their proximity to dirt and disgust (Bataille, 1999). Formulated as an abject class are all those whose utter impoverishment (culturally, financially and/or socially) leads them to and keeps them attached to an inescapable life of dirty work and regular contact with what the rest of society manages to avoid or at least conceal. This concept of abjection was further developed by the French feminist writer Julia Kristeva in her book Powers of Horror: Essays in Abjection (Kristeva, 1982). Much more than Bataille, Kristeva concentrated upon the intra-psychic aspects of abjection, the psychological attributions associated with abject objects and the relationship between those abject objects and their abject subject. Drawing upon both Bataille and Kristeva, abjection can be theorised as a form of social division or social status with its accompanying intra-psychic and interpersonal 'state of being'.

The abjection of the fourth age might seem to be concerned with incontinence, a lack of selfcare or the seemingly purposeless behaviour of older people with dementia. All these may well serve as signifiers of people's abject circumstances, but they are rendered more 'pitifully' abject by an evident lack of agency - the individual's apparent inability to conceal his or her 'failings' whether through physical weakness mental limitation or other factors. This combination of 'objectified frailty' and 'distanced abjection' lends itself to the process of 'othering' - that failure to acknowledge the subjective agency of an older person that constitutes the third vector in the social imaginary of the fourth age. 
Othering is essentially a catch-all term to describe the attributions made by other people of persons who seem powerless to assert their own identity or realise their social agency. As a concept, 'othering' has a long and complex history within the academy. Its systematic use in cultural studies has been to represent the process whereby identities are attributed to those who have for various reasons become subject to the power of another (Spivak, 1988). This process was first modelled on the relationship of colonial peoples to their imperial rulers, as 'subaltern subjects' who were given no voice as subjects in their own right. Denied their own subjectivity, they exist as forever third persons in forever third worlds. Spivak helped develop the academic field of 'post-colonial' studies where the narratives and practices through which particular colonial regimes 'othered' those whom they ruled over were explored. While the concept of othering was first explored within such post-colonial contexts, more recently it has been applied to health and social care settings to describe how staff controlling health or social care 'other' those subject to particular care regimes (Canales, 2000; 2010; McCallum, 2002).

Canales has suggested that a distinction be made between practices that actively support an 'inclusionary' othering and those that adopt a more traditional 'exclusionary' othering associated with marking and naming those considered different (Canales, 2000). As she points out, "it is through others that we come to see and define self, and it is our ability to take that role that allows us to see ourselves through others." (Canales, 2000: 17). She argues that the process of othering is not inherently 'bad' and that it can enable people in very different circumstances engage with each other, as 'others', without thereby oppressing or being oppressed. Accepting difference and otherness, even non-reciprocity, she suggests, can still make care possible whether from a sense of obligation or from feelings of pity, even 
though care is constrained by this sense of intractable 'otherness'. Thus conceived, othering can inform even if it does not determine the moral imperative of care, that fourth vector constituting the social imaginary of the fourth age.

\section{The imperative of care and the moral identity of the fourth age}

In charting the 'social death' implied by the loss of agency embedded within the fourth age, we soon come up against the moral imperative of care. The tradition of offering charity to orphans and widows, the aged and infirm pre-dates modernity. It forms a common theme in all the Abrahamic religions. In Europe, the Reformation and the Counter-Reformation of the 16th and 17th centuries sharpened the distinction between the deserving and undeserving poor. Previously, it has been argued, the act of giving was considered more important than the character of the recipients. Charity was a practice expected of its adherents by their religious affiliation to secure their own salvation. The secularisation of poverty associated with the Reformation lead to more attention being paid to the recipients - on who deserved 'caritas'. Subsequent developments continued to privilege the impotent poor, especially the most impotent, the aged and infirm who were not only offered better accommodation and diet in the alms-houses, poorhouses and workhouses but were also deemed more eligible for 'outdoor relief'.

When the machinery of the British poor law was dismantled during the first half of the twentieth century, the greatest number of people occupying 'long stay beds' - in the workhouses, the infirmaries and the various asylums - were the aged sick. They were also among the last to gain access to the new hospital regimes which had thus far excluded them (Smith, 1990). As the post- war welfare state lumbered into action, 'care of the aged' presented it with some of its greatest challenges. Though among the most deserving, the aged 
sick were also among the least rewarding to look after, creating a degree of ambivalence on the part of the post-war welfare state. The aged sick could not be ignored. Everyone agreed that 'something needed to be done'. But what was most often done typically took place out of sight of the collective 'us' that constituted our collectively imagined 'welfare society' and much of it was, in retrospect, inadequate, inefficient and at times uncaring (Webster, 1991).

Foremost among the challenges arising from the integration of old people into the health care system was agreeing and organising that care - who needed it, where should it take place and how should it be funded. As always, the aged sick most often received care within the family, by individuals whose relationship to the person receiving care was that of a wife, daughter, husband, son or daughter-in-law. Care-giving responsibilities followed from the moral identities assigned within and assumed by members of the family (Finch, 1989). By the 1980s as part of the move toward 'community care' the wives daughters husbands sons and daughters-in-law began to be re-labelled 'carers'. Surveys were conducted exposing the plight and even the 'oppression of carers' (Dalley, 1991). The aged sick had already been relabelled 'the elderly mentally and physically infirm'; now those who helped them were known as their 'carers'. Local authorities complained that they could no longer afford extending subsidised accommodation to those who were merely socially needy or poor; hospitals on the other hand were becoming uncomfortably blocked by their aged patients whose care they asserted did not 'need' the costly ministrations of hospital doctors and nurses. Care needed to be re-located within the community, and in any case, institutions were breeding grounds of an exclusionary othering. Keeping elderly mentally and physically infirm persons at home was morally and financially a better option. 
Signs of an ecologically framed crisis were increasingly predicted - rising tides of dementia, tsunamis of frailty, an apocalyptic demography of agedness was being formulated out of the ageing of already ageing societies (Robertson1993; Zeilig, 2014). How could this crisis be managed if not by ever tighter targeting and ever finer distinctions of frailty? As the networks of formal care were drawn tighter, long term care was increasingly purchased from the non state sector as offering 'better value'. What had once been an exclusive and exclusionary service for an elite few, the clients of private home nursing and nursing homes, was now expanded into a democratic market place whose customers were not so much the wealthiest but the most aged sick. Would such care prevent further 'frailure'? Would it ameliorate the abjection of the frail and the isolated older person, replacing the exclusionary 'othering' of the past with an inclusionary care service for the future? Or might it have the opposite effect - expanding the possibilities of abjection, and more profoundly othering care recipients by constructing narratives for them of person-centred, paid compassionate care, service cultures of dementia rendered incoherent by the everyday practices that were shaped not by the wishes of informed and well off elderly customers but by the abjection and frailures of these newly designated 'clients'?

'Piss on your pity' is a slogan that has been used by mostly younger sections of the disability movement to re-assert their agency in the face of 'care'. But who can speak out for those who are unaware of, or unable to politicise, their incontinence, who, conveniently packaged in old age nappies are labelled 'doubly incontinent, change regularly'? Should we avoid feeling pity for them and insist on their status as clients engaged in an equal exchange of cash for care? Or must we wear hope with a mourning band when confronted by what Lionel Trilling has called "the essential immitigability of the human condition" (Trilling, 1972: 156)? Of course we should try harder, 'fail better' in Beckett's words (Beckett, 2009). Might 
we sometimes however also need to accept the idea of 'social death' as itself a kind of compassionate care, treating dementia as an involuntary haven for those for whom being forever a fully human agent has become simply too hard and too painful? ${ }^{1}$

\section{Social death and dementia}

The concept of a social death was introduced into the social sciences in the 1960s by Glaser and Strauss who observed how, in hospital, some people often seemed to die socially - as people - before they died biologically - as bodies (Glaser and Strauss, 1966). Drawing upon their work, Mulkay and Ernst have defined social death as "the cessation of the individual person as an active agent in other's lives" acknowledging that individuals may be dead for some parties yet socially alive for others (Mulkay and Ernst, 1991: 178). They identified the 'elderly' as a group particularly prone to undergoing this kind of social death, especially in the context of age-segregated nursing and residential homes and suggested that "a basic distinction [be made] between those who are deemed to be close to death and those for whom death is not thought to be imminent" (Mulkay and Ernst, 1991: 183). This distinction they summarised as one between the fit and the frail, with the former serving to define more clearly the death of the latter. The ageing of later life in contemporary societies, Mulkay and Ernst concluded, meant that "a substantial part of those extra years of biological functioning that have been acquired ... are likely to be spent... in a condition closely approaching social death" (Mulkay and Ernst, 1991: 194). The parallels between Baltes and Laslett's 'third versus fourth ages' approach are clear in this formulation.

\footnotetext{
${ }^{1}$ This is in essence the position recently articulated by the British actress, Sheila Hancock, in her comments on the 'selfishness' of those older people who have not planned their long term care (Daily Telegraph, Wednesday, $29^{\text {th }}$ April, 2015)
} 
The term 'social death' was applied to people with dementia in a series of papers by Helen Sweeting. Sweeting and her colleague Mary Gilhooly outlined the process that led people with dementia to becoming 'socially dead' in the minds of their carers (Sweeting and Gilhooly, 1992; 1997). They drew links with, while making distinctions between the loss of self or personhood ascribed to dementia and the idea of social death. They pointed out that the family may often remain actively involved with patients in a vegetative state, illustrating the "example of social life in the face of loss of personhood" while others may be treated as socially dead despite the existence of personhood such as when "a doctor may discuss a diagnosis with other staff in the patient's presence as if they were an inanimate object" (Sweeting and Gilhooly, 1997: 98).

Sweeting and Gilhooly observed a variable set of statuses ascribable to the people with dementia by their relatives. These they broadly classified into (a) those who were "socially alive and treated with attributed personhood", (b) those who were "socially alive but treated without attributed personhood" and (c) those who were "socially dead and treated without attributed personhood". Importantly, they found that both the loss of personhood and the idea of social death made sense to and were found meaningful to the carers themselves even if they did not necessarily apply these concepts to their family member.

How might these statuses or social positions - a loss of personhood, social death and the need to be cared for - be reconciled? Is caring an antidote to letting someone die socially, or can it also be one aspect of realising a social death? Is social death primarily a matter of not caring for a person, or of care without really caring about the person, providing disinterested and dispassionate care to mentally frail citizens whose personhood is past? Can these various concepts of social death, the imperative of care and the fourth age be (more) usefully linked? 


\section{Social death, personhood and the moral imperative of the fourth age}

Since the publication of Mulkay and Ernst's paper and Sweeting and Gilhooly's work, little attention has been given to the idea of social death among older people with dementia. The early 'carer-focused' literature that spoke of dementia as the 'loss of self' (Small et al., 1998: 292) has been replaced by more 'person-centred' narratives that seek to promote inclusionary practices (Branelly, 2011). The implication is that narratives of 'loss of self' and 'social death' did not so much describe as ascribe a negative status to the person with dementia, contributing in effect to the exclusionary othering of people with dementia through a process that was described by Kitwood as 'malignant social psychology' (Kitwood \& Bredin, 1992; Kitwood, 1993; 1997).

The turn from what might be deemed carer- lead narratives to narratives that acknowledge and sometimes privilege the perspective of the person with dementia can be seen as a turn away from exclusionary toward inclusionary othering - a rescuing of persons from disappearing into the darkest shadows of the fourth age. Giving space to persons with dementia, respecting their wishes, supporting their identity and recognising their individuality seem crucial in preventing the individual's de-personalisation and their social dying. The work of Tom Kitwood and his colleagues focused on developing the person with dementia's agentic potential in order to be able to act within the world. The crucial aspect of care within this person-centred philosophy was to change the cultural and social circumstances that undermine the personhood of the individual with dementia.

The focus upon the individual that is implicit in this model of dementia care has been criticised by Barlett and O'Connor (2007) who argue that the issue of power remains 
unaddressed. Instead of focusing upon prioritising personhood, they advocate an approach based on the politics of citizenship. A person with dementia is entitled to the same from life as everyone else; it is their shared citizenship, not their personhood that counts. However, as citizenship tends to assume the individual's capacity to exercise citizen rights and responsibilities it needs further elaboration if it is to avoid the essentialism that besets ideas of personhood. Bartlett and O'Connor argue that we should not privilege any one notion of citizenship and instead see citizenship as the outcome of 'acts of power' in which people with dementia are actors co-constructing their own reality. Even person-centred care viewed through the lens of citizenship remains a form of othering however and has itself been subject to a degree of criticism. Behuniak (2010) for example has pointed out that what often lies behind the person centred approach is a position focused on the idea of the person as a legal construct. Even if these legal constructs are ascribed the status of citizens rather than persons it does not change this point of reference. Instead she argues people with dementia should be regarded as 'vulnerable persons' who may need at times special protection or care because of diminished capacity. This, she asserts, does not strip the person of rights, dignity or citizenship because it is guided by the shared empathy that is common to us all. Such empathy leads to a compassion that is rooted in an equality between human beings and an assumption of human autonomy. These she sees as the higher forms of power which integrate rather than exclude people with dementia from society.

It is problematic, however, that this critique of person-centred approaches leaves the issue of compassion in the same situation as those criticising ideas of pity. Who decides what for whom? This leads once again to the moral imperative of care. While it might be more virtuous to see the debate in terms of the protection of rights to participate as much as possible rather than ensuring people's protection from themselves as failed agents, the social 
imaginary of the fourth age cannot be brushed aside simply by re-constructing the narratives of care. How the person with dementia is helped to maintain their position in society is ultimately down to the efforts of others. It is not a matter of individual choice. As all the positions outlined above concur it involves a degree of social intent and the necessary diffusion of power from persons with dementia towards people without it. Rather than denying this process, it is important to recognise and support it, giving due value to the person with dementia in large part by giving due value to those who have to act for such persons. It may be radical but it is not obviously restitutive to 'piss on their pity'. By showing concern for those who are concerned about - and who care for - the person with dementia; by enabling them, one might say, to hold off the shadows of the fourth age as long as they can and as long as they desire to.

\section{Conclusion}

The fourth age can be understood as a feared imaginary of old age. Much of that fear settles on the loss of agency that is associated with frailty, particularly mental frailty and the perceived abjection of an undignified journey toward non-existence. The presence and salience of such a social imaginary, we feel, helps explain the widespread fear of late life dementia reported among those reaching or already entering later life (Breining et al., 2014; Cantegreil-Kallen and Pin, 2012). Part of that fear can be represented as a fear of undergoing a premature social death - of becoming irrevocably lost to one's self as a concerned agent involved with the business of living.

Alongside the abjection, frailty and loss of social agency which fashion the fourth age's imaginary there exists a moral imperative to care that ties those in the shadows of the fourth age to the rest of the social world. Collective and familial expressions of this imperative of 
care has a long history across many cultures and within many religious traditions. Social death, we suggest, is unimaginable without the moral imperative to care and both can be understood as aspects of the fourth age's social imaginary. Their intimate linkage arises through the development of caregiving narratives and practices within the family and within social relationships that operate between the fit and the frail. The paradox lies in what orients the transformation of care; the perceived changes that are viewed not as change and certainly not as 'development' but as increased dependency and decreased agency.

Dementia presents an acute form of this paradox. As the updating of self begins to fail, it is increasingly what Ricoeur has called the 'sameness of self' that serves to maintain personhood (Ricoeur, 1992). With an increasing disconnection between the changes to self that others begin sooner or later to observe, the maintenance of sameness (identity) comes at a growing interpersonal cost. It becomes harder to treat the person as the same self when the person's actions, attitude and discourse bear growing witness not just to change but to otherness. Within this conflict between self-sameness and self-change, care takes on new powers, including the power to effect or deny the social death of the person as the past self, who is deemed other to that same self.

Such a death might once have been wished for by the person affected, as a way of preventing the indignity of becoming evidently other to oneself, an indignity that the carer is helpless as carer - to prevent . In such circumstances, pity more than compassion might seem the more appropriate, or more possible, emotional response with which to carry on caring for someone who has ceased to be the same self, who has become 'other'. Whether or not this kind of acceptance constitutes social death, or whether or not it negates some essentialised concept of 'personhood', we would argue that it does not necessarily constitute not caring 
even if it is caring in memory of a past self no longer seemingly present. Recognising and valuing the social being of the person being cared for in their past sameness and in their present difference can still be caring about the person with dementia - in the sense of protecting and providing for that person. However, we have argued this also requires recognising and valuing the social being of the person or persons who are doing the caring, protecting them too from the darker and depersonalising aspects of the fourth age. Sometimes that might mean choosing a social death. 


\section{References}

Baltes, P.B. and Smith (2003). New frontiers in the future of aging: from successful aging of the young old to the dilemmas of the fourth age. Gerontology, 49 (2): 123-135.

Baltes, P.B. (2006). Facing our limits: Human dignity in the very old. Daedalus, 135 (1) 3239.

Bartlett, R., \& O'Connor, D. (2007). From personhood to citizenship: Broadening the lens for dementia practice and research. Journal of Aging Studies, 21(2), 107-118.

Bataille, G. (1999). Abjection and miserable forms (trans. Y. Shafir), in [ed.] S. Loetinger, More \& Less. MIT Press: Cambridge, Mass, pp. 8-13. .

Beckett, S. (2009) Worstward Ho!, in Company/ Ill Seen, Ill Said/ Worstward Ho/ Stirrings Still. London, Faber \& Faber.

Behuniak, S. M. (2010). Toward a political model of dementia: Power as compassionate care. Journal of Aging Studies, 24(4), 231-240.

Brannelly, T. (2011). Sustaining citizenship: People with dementia and the phenomenon of social death. Nursing Ethics, 18(5), 662-671.

Breining, A., Lavallart, B., Pin, S., Leon, C., Moulias, S., Arwidson, P., Beck, F., Berr, C. and Verny, M. (2014). Perception of Alzheimer's disease in the French population. The Journal of Nutrition, Health \& Aging, 18(04), 393-399.

Caddell, L.S. \& Clare, L. (2010). The impact of dementia on self and identity: a systematic review. Clinical Psychology Review, 30(1), 113-126.

Canales, M. K. (2000). Othering: toward an understanding of difference. Advances in Nursing Science, 22(4), 16-31.

Canales, M. K. (2010). Othering: Difference understood?: A 10 -year analysis and critique of the nursing literature. Advances in Nursing Science, 33(1), 15-34. 
Cantegreil-Kallen, I. and Pin, S. (2012). Fear of Alzheimer's disease in the French population: impact of age and proximity to the disease. International Psychogeriatrics, 24(01), 108-116.

Castoriadis, C. (1987). The Imaginary Institution of Society. Cambridge, Polity Press.

Dalley, G. (1988) Ideologies of caring: rethinking community and collectivism Basingstoke Macmillan Education,

Davis, D.H. (2004). Dementia: sociological and philosophical constructions. Social Science \& Medicine, 58 (2) : 369-378.

Dewing, J. (2008). Personhood and dementia: Revisiting Tom Kitwood's ideas. International Journal of Older People Nursing, 3 (1), 3-13.

Eustache, M. L., Laisney, M., Juskenaite, A., Letortu O, Platel H, Eustache F \& Desgranges B (2013). Sense of identity in advanced Alzheimer's dementia: A cognitive dissociation between sameness and selfhood? Consciousness and Cognition, 22 (4) : 1456-1467. Finch J. (1989). Family Obligations and Social Change. Cambridge: Polity Press. Furness, Hannah (2015). Sheila Hancock: it is stupid to avoid thinking about living in a care home, Daily Telegraph, Wednesday, 29th April, 2015.

(Accessed 29th April, 2015 via:

http://www.telegraph.co.uk/news/health/elder/11569456/Sheila-Hancock-it-is-stupid-toavoid-thinking-about-living-in-a-care-home.html)

George, D.R. (2010). The art of medicine: Overcoming the social death of dementia through language. The Lancet, 376, 586-587.

Gilleard, C, and Higgs, P. (2010). Aging without agency: Theorizing the fourth age Aging \& Mental Health, 14 (2), 121-128.

Gilleard, C. and Higgs, P. (2013). The fourth age and the concept of a 'social imaginary': A theoretical excursus. Journal of Aging Studies, 27 (4), 368-376. 
Gilhooly, M. L., Sweeting, H. N., Whittick, J. E., \& McKee, K. (1994). Family care of the dementing elderly. International Review of Psychiatry, 6(1), 29-40.

Glaser, B.G. \& Strauss, A.L. (1966). Awareness of Dying. New Brunswick, NJ,: Transaction Publishers.

Hertogh, C.M., de Boer, M.E., Dröes, R.M. \& Eefsting, J.A. (2007). Would we rather lose our life than lose our self? Lessons from the Dutch debate on euthanasia for patients with dementia. The American Journal of Bioethics, 7 (4): 48-56.

Higgs, P. and Gilleard, C. (2015). Rethinking Old Age: Theorising The Fourth Age. London: Palgrave Macmillan.

Hughes, J.C., Louw, S.J. \& Sabat, S.R. (eds.). (2006). Dementia: Mind, Meaning, and the Person. Oxford: Oxford University Press.

Kitwood, T. \& Bredin, K. (1992). Towards a theory of dementia care: personhood and wellbeing. Ageing and Society, 12 (3): 269-287.

Kitwood, T. (1993). Towards a theory of dementia care: the interpersonal process. Ageing and Society, 13 (1): 51-67.

Kitwood, T. (1997). Dementia Reconsidered: The person comes first. Buckingham: Open University Press.

Laslett, P. (1989). A Fresh Map of Life. London: Weidenfeld \& Nicolson.

Laslett, P. (1996). A Fresh Map of Life. $2^{\text {nd }}$ edition. London: Macmillan Press.

Mulkay M. and Ernst, J. (1991). The changing profile of social death. European Journal of Sociology, 32 (1) : 172-196.

MacCallum, E. J. (2002). Othering and psychiatric nursing. Journal of Psychiatric and Mental Health Nursing, 9(1), 87-94.

Neugarten, B.L. (1974). Age groups in American society and the rise of the young-old. The Annals of the American Academy of Political and Social Science, 415(1), 187-198. 
Palmore, E., \& Cleveland, W. (1976). Aging, terminal decline, and terminal drop. Journal of Gerontology, 31(1), 76-81.

Ricoeur, P. (1992). Oneself as Another. (trans. K Blamey) Chicago: University of Chicago Press.

Small, J. A., Geldart, K., Gutman, G., \& Clarke Scott, M. A. (1998). The discourse of self in dementia. Ageing and Society, 18(03), 291-316.

Smith, F.B. (1990). The People's Health, 1830-1910. London: Weidenfeld \& Nicolson.

Spivak, G. C. (1988). Can the subaltern speak? In C. Nelson and L. Grossberg, (eds.)

Marxism and the Interpretation of Culture, Macmillan: Basingstoke, 271-313.

Sweeting, H. N. \& Gilhooly, M. L. (1991). Doctor, am I dead? A review of social death in modern societies. OMEGA--Journal of Death and Dying, 24 (4) : 251-269.

Sweeting, H., \& Gilhooly, M. (1997). Dementia and the phenomenon of social death. Sociology of Health \& Illness, 19(1), 93-117.

Taylor, C. (2004). Modern Social Imaginaries. Durham, NC: Duke University Press.

Trilling, L. (1972) Sincerity and Authenticity. Cambridge, Mass.: Harvard University Press. Webster, C. (1991). The elderly and the early national health service, in [eds.] M. Pelling \& R. M. Smith, Life, Death and the Elderly in Historical Perspective. Routledge, London,138159. 